\title{
The environmental intention of owner-managers: The role of entrepreneurial orientation in Tunisian industry
}

\author{
Azzedine Tounés \\ INSEEC School of Business \& Economics \\ 25, rue de l'universit_e, Lyon 69007, France \\ INSEEC Research Center, France \\ atounes@inseec.com \\ Erno T. Tornikoski \\ University of Exeter Business School, UK \\ Grenoble Ecole de Management, France \\ E.Tornikoski@exeter.ac.uk \\ Fafani Gribaâ \\ Institut Sup_erieur de Gestion (ISG), Sousse, Tunisia \\ gribaafafani@yahoo.f
}

\begin{abstract}
Environmental intention is a key predictor of environmental behavior but there is little theoretical and empirical evidence on environmental intention, especially in developing countries. To address this gap, we study the environmental intention of industrial ownermanagers in Tunisia. Based on Tunisia's participation in sustainable development programs of the United Nations, it seems to be representative of developing countries. We study the environmental intention of owner-managers through a multidimensional concept rarely mobilized in the environmental field, namely, entrepreneurial orientation. We test our hypotheses in the textile-clothing industry, which is the source of significant amounts of water and air pollution and is among the priority industries designated by the Tunisian state as part of an environmental improvement program in 2014.
\end{abstract}

Based on a survey of 226 owner-managers, the results show that the three dimensions of entrepreneurial orientation, namely, innovativeness, proactiveness, and risk-taking, are robust to predict the environmental intention of Tunisian owner-managers.

Keywords: Developing country, environmental intention, entrepreneurial orientation, textileclothing industry, Tunisia, 


\section{Introduction}

The development of environmental intention among owner-managers is a pre-requisite for any environmental behavior taking place in their small and medium-sized enterprises (SMEs) (Rodríguez-Barreiro et al., 2013). In the line of Hines et al. (1987), specialized scholars often used the concept of intention to predict environmental behavior (Rodríguez-Barreiro et al., 2013) Lo, et al., 2012; Lülfs \& Hahn, 2014). However, despite the importance of the environmental intention in predicting owner-managers' behavior toward the environment (Martin-Pena et al., 2010), it remains a poorly studied concept (Hing Lo et al., 2012; MartinPena et al., 2010; Tounés et al., 2018). Indeed, our knowledge of the factors contributing to the development of environmental intention among owner-managers remains weak especially in developing countries because earlier studies in the field of the environment have mainly been focused on developed countries in Europe and in the United States (Jamali \& Mirshak, 2007; Jamali et al., 2015; Koleva \& Gherib, 2012; Roxas \& Coetzer, 2012).

In this study, we are interested in the concept of environmental intention in the context of a developing country, namely Tunisia. To strengthen the attractiveness of companies to foreign investors (Labaronne \& Gana-Oueslati, 2011), Tunisian industries have undergone significant changes in regulatory and social frameworks with respect to the environment (Koleva \& Gherib, 2012). The post-revolutionary context has increased social and institutional pressures to limit environmental degradation by Tunisian companies. Among these institutional pressures, constitutional and legislative transformation started in 2014 to support Tunisian entrepreneurs in the implementation of environmental innovations.

However, despite these ambitious incentive systems, the environmental commitment of Tunisian owner-managers in the industrial sector remains low (Gherib \& Ghozzi-Nékhili, 2012; Hamdoun et al., 2016). In 2014, the National Conference on Sustainable Development highlighted the delay of Tunisian owner-mangers in catching up to matters of environmental concern. Significant discrepancies have been noted between environmental requirements and managerial practices of Tunisian owner-managers (ANDD, 2014). The legislative and regulatory frameworks in Tunisia, whether coercive or incentive based, have limited impact on the intention of Tunisian owner-managers regarding the environment (Tounés et al., 2018). The reduced effect of these regulations suggests that other factors can influence environmental intention. In this respect, the personal traits of owner-managers are decisive in the environmental field (Hockerts \& Wüstenhagen, 2010: Spence et al., 2011), especially in 
developing countries (Jamali \& Mirshak, 2007). Among these individual characteristics, York and Venkataraman (2010) and DiVito and Bohnsack (2017) argue that research on the environment requires paying attention to the entrepreneurial orientation of owner-managers.

To shed light on environmental intention, we pay particular attention to the entrepreneurial orientation of owner-managers. Courrent et al. (2016) note that the entrepreneurial orientation of SME owner-managers influences their environmental practices. Kuckertz and Wagner (2010) argue that the entrepreneurial orientation of owner-managers is the basis for studying the intention of implementing environmental practices. To explain the links between the entrepreneurial orientation and environmental intention of owner-managers, we focus on the manufacturing sector, which is one of the biggest polluters of the environment (Williamson et al., 2006). In the Tunisian context, industrial companies are particularly concerned about waste management and air pollution (Gherib \& Ghozzi-Nékhili, 2012). Our analysis focuses on the textile-clothing industry, which the Tunisian state prioritized under a 2014 environmental improvement program. In essence, the main purpose of this study is to analyze the contribution of entrepreneurial orientation to the formation of the environmental intention of SME owner-managers in the Tunisian textile-clothing industry.

The rest of this article is structured in four sections. In the first section, we propose the theoretical framework and present our research hypotheses. In the second section, we outline our methodological approach. In the third section, we describe the results of the research. In the last section, we discuss these results based on their relevance to the literature. Finally, we conclude with theoretical, methodological, and managerial implications. We also discuss the limitations and perspectives of our research.

\section{Theoretical framework and hypotheses}

Intention captures the motivational factors that influence behavior (Ajzen, 1991). Based on Ajzen and Fishbein (1980), intention refers to the perception of the probability of adopting given behavior. In the environmental field, intention is poorly defined. However, Kuckertz and Wagner (2010) note that the concept is crucial to understanding environmental behavior. Martin-Pena et al. (2010) state that environmental intention determines the way in which managers respond to environmental issues. 
We study the concept of environmental intention through the entrepreneurial orientation of the owner-managers. Examining this relationship fill the gap in the literature because there is little research examining sustainable development practices from the viewpoint of entrepreneurial orientation (Hall et al., 2010). Few studies bridge the gap in the literature and link entrepreneurial orientation to environmental development (DiVito and Bohnsack, 2017). According to Ayuso \& Navarrete-Báez (2018), our understanding of the conceptual mechanisms that link entrepreneurship with environmental development is still insufficient. However, these authors note some evidence in the literature that entrepreneurial orientation may affect environmental development strategies. The concept of entrepreneurial orientation is a key variable for understanding entrepreneurial emergence in the field of the environment (Kuckertz \& Wagner, 2010). This concept reflects the entrepreneurial strategy of firms in respect of the environment (Roxas \& Coetzer, 2012).

For DiVito and Bohnsack (2017) and Hall et al. (2010), an important domain of literature on sustainable entrepreneurship argues that entrepreneurial actions contribute to solving complex ecological and environmental issues and act as a catalyst for industrial transformation. Referring to the literature on sustainable entrepreneurship, entrepreneurial action is needed to recognize opportunities, create innovations and generate economic rents while addressing ecological and environmental challenges (DiVito and Bohnsack, 2017; Shepherd and Patzelt, 2011). DiVito and Bohnsack (2017) argue that entrepreneurial orientation, as decision-making processes, structures and behavior to exploit opportunities, can help researchers to understand in more depth how entrepreneurs are committed in ecological concerns to exploit opportunities and disrupt the established unsustainable order of industries. This process is shaped by entrepreneurial orientation of entrepreneurs.

Traditionally entrepreneurial orientation is related to economic growth and wealth creation (Baker \& Sinkula, 2009; de Guimarães et al., 2018; DiVito and Bohnsack, 2017). However, the role of entrepreneurial orientation may be important for businesses commitment to environment particularly when the pressures of customers or other stakeholders are weak. Jansson et al. (2017) posit that given the importance of entrepreneurial orientation to the firm's long-term goals and strategies, it is possible to argue that this orientation could explain the manner in which the managers address sustainability and environmental aspects of their operations. 
Ayuso \& Navarrete-Báez (2018) note that entrepreneurial orientation is positively associated with sustainable commitment, particularly regarding the environment. Researches by de Guimarães et al. (2018) and Jansson et al. (2017) sustain that entrepreneurial orientation influences environmental practices because managers see both market and entrepreneurial advantages of sustainability. Entrepreneurial orientation is a strategic driver that precede environmentally friendly behavior (de Guimarães et al. (2018); it influences the recognition, evaluation and exploitation of sustainability decision alternatives (DiVito and Bohnsack, 2017; Hahn et al., 2014).

Entrepreneurial orientation indicates a way of acting of entrepreneurs and their strategic posture (Ayuso \& Navarrete-Báez, 2018). Thus, entrepreneurial orientation is theorized according to Miller's (1983) approach. Drawing in this approach, we consider in our research entrepreneurial orientation as a multi-dimensional construct with three components: risktaking, innovativeness, and proactiveness (Covin \& Miller, 2013; Covin \& Slevin, 1989; Dess et al., 2011; Kreiser et al., 2010; Madsen, 2007; Slevin \& Terjesen, 2011). These three dimensions vary separately and independently (Covin \& Slevin, 1991; Lumpkin \& Dess, 1996, 2001), allowing a richer conceptualization of entrepreneurial orientation (Lumpkin \& Dess, 2001).

Each dimension of entrepreneurial orientation has clear connections to environmental business practices (Jansson et al., 2017) and is related to the managerial challenges posed by sustainable development (Ayuso \& Navarrete-Báez, 2018) and environment (Kuckertz and Wagner, 2010). For example, eentrepreneurs challenge the established industrial order through the innovation of more environmental practices on pursuing simultaneously organizational and sustainability goals (DiVito and Bohnsack (2017); innovativeness enhance the ability to develop environmental business opportunities (Schaltegger \& Wagner, 2011). Managers' proactiveness takes advantage of public mechanisms to incentivize and regulate the environment (Walker et al., 2014). Taking risks may lead in an increasing way to try new untested environmental techniques to respond to challenges in the natural environment (Kreiser et al., 2010).

Based on the theoretical arguments above, our interest in this paper addresses the gap in the literature and aim to examine how entrepreneurial orientation fit with environmental concerns. In this way, our study contributes with understanding of how entrepreneurial 
orientation of owner-managers influence their environmental intention. We postulate that each dimension of entrepreneurial orientation - innovativeness, proactiveness and risk-taking - has a significant impact on the environmental intention of owner-managers.

\section{Innovativeness and environmental intention}

Innovativeness is a fundamental concept in the field of entrepreneurship (Kuckertz \& Wagner, 2010). It reflects the promotion of new ideas by companies and the encouragement of creative processes on technological products and processes (Lumpkin \& Dess, 1996). Innovativeness is an important mean by which companies pursue new opportunities (Madsen, 2007).

Innovativeness is of increasing interest to researchers in the environmental field (York \& Venkataraman, 2010). According to Hockerts and Wüstenhagen (2010), Larson (2000), and Sharma et al. (2007), innovativeness characterizes the environmental activities of managers. It is the ability to identify opportunities by transforming technology and products (Larson 2000), organizational methods (York \& Venkataraman, 2010) and market conditions (Dibrell et al., 2011) for the protection of the environment. Environmental commitment requires continuous innovation to reduce the adverse effects of business activities on nature and humans (Bansal et al., 2014; Larson 2000; Schaltegger \& Wagner, 2011). In the industrial sector, innovativeness is at the heart of environmental issues (Hockerts \& Wüstenhagen, 2010; Kuckertz \& Wagner, 2010) in light of scientific progress in the environmental sciences (Bansal et al., 2014). Innovativeness minimize the industrial activity impacts, whether in decreasing the residue generation, reducing the natural resources' consumption or using alternative energy (de Guimarães et al., 2018).

A large part of the literature studies innovativeness in order to predict the environmental intention of SME managers (Garay et al., 2017; Pinget et al., 2015). Thus, innovativeness influences the intention to undertake measures to protect the environment (Kuckertz \& Wagner 2010; Schaltegger \& Wagner, 2011). In Tunisia, managers' innovativeness determines the environmental management of industrial firms (Hamdoun et al., 2016). In light of these academic insights, we formulate our first hypothesis.

Hypothesis 1: Innovativeness positively influences the environmental intentions of ownermanagers in Tunisia. 


\section{Proactiveness and environmental intention}

According to Covin and Slevin (1986), proactivity refers to the fact that a company is rather a leader rather than a follower of its competitors in the key areas of the introduction of new products or services, operating technologies, and managerial techniques. In reference to Dess and Lumpkin (1996), proactive individuals demonstrate an openness to new activities and new products. According to Kreiser et al. (2010), Lumpkin and Dess (2001), and Lumpkin et al. (2010), the concept of proactiveness refers to the search for opportunity, or the prospective vision of shaping the environment before competitors.

Relative to the field of the environment, proactiveness is the subject of many theoretical developments (Walker et al., 2014). It characterizes the anticipation of the environmental legal framework to compete with competitors by identifying new opportunities for technological changes in manufacturing systems, processes, products, and services (AragónCorrea \& Sharma 2003; Sambasivan et al., 2013; Sharma et al., 2007). Proactiveness characterizes the anticipation of the environmental legal framework. A proactive manager initiates changes in the company's environmental strategy (Brulhart \& Gherra, 2015) rather than reacting to events and complying with environmental legislation (Aragón-Correa \& Sharma, 2003; Sharma et al., 2007). In addition, a proactive manager considers at a high level stakeholder pressure to treat environmental concerns (Brulhart and Gherra 2015; MurilloLuna et al., 2011; Rueda-Manzanares et al., 2008).

It should be noted that a significant part of research examining the role of proactiveness in the environment is concentrated in developed societies, thereby marginalizing developing countries. A careful examination of this role in different contexts provides contingent responses to the global environmental crisis (Walker et al., 2014). In developing countries, industries are undergoing structural changes accelerated by the harmonization of environmental regulations with those of major Western partners (Koleva \& Gherib, 2012; Rettab et al., 2009). In Tunisia, the support offered as part of environmental upgrades would encourage business managers to identify environmental opportunities and deploy proactive environmental strategies (Turki, 2014). In light of this literature and like Murillo-Luna et al. (2011), we assume that proactiveness has a significant effect on the environmental intention of owner-managers. Thus, we propose our second research hypothesis. 
Hypothesis 2: Proactiveness positively influences the environmental intentions of ownermanagers in Tunisia.

\section{Risk-taking and environmental intention}

Risk-taking means a tendency to venture into new markets by committing significant resources to uncertain projects and substantial potential losses (Covin \& Slevin, 1991; Lumpkin \& Dess, 1996; Madsen, 2007; Morris et al., 2011). While entrepreneurial activities offer great opportunities for growth (Covin \& Slevin, 1989), they also lead to high levels of risks (Boso et al., 2013).

The effect of risk is poorly studied in the environmental field (Cai et al., 2016). However, in the literature, the environment is presented not only as an area of risk control or prevention, but also as a risk in itself (Spence et al., 2011). To this end, risk is one of the factors that seem to play an important role in managers' decisions to invest in environmental activities (Hockerts \& Wüstenhagen, 2010). According to Sharma (2000), a proactive environmental strategy requires managers who are able to take risks. Cai et al. (2016) note that the managers of SMEs incur financial and managerial risks because return on investment is long term (Brulhart \& Gherra 2015; Spence et al., 2011) and commercial success is uncertain (Wijethilake et al., 2018). In addition, these managers perceive that environmental commitment generates additional operational risks (Fisher et al., 2009) and weakens their businesses vis-à-vis competitors (Simpson et al., 2004). However, risk-taking in the environmental field can bring certain benefits, such as meeting the expectations of stakeholders, accessing new markets, and increasing the company's performance (Courrent et al., 2016).

Among the factors that may further influence the environmental risk-taking of managers, political and social contexts can be decisive (Cai et al., 2016). Researchers argue that managers facing highly uncertain business environments tend to take more risks than do managers operating in less turbulent environments (Aragón-Correa \& Sharma, 2003). In developing countries, periods of economic and social reform are characterized by a degree of uncertainty that requires managers to have high-risk propensity. After the post-revolution period of 2011, Tunisia left an institutional void in the environmental field (Koleva \& Gherib, 2012; Turki, 2014). This context of uncertainty seems to reinforce the links between the propensity to risk-taking and the willingness of Tunisian owners-managers to set up practices 
in favor of the environment (Turki, 2014). Thus, based on these literature elements, we formulate the third research hypothesis.

Hypothesis 3: Risk-taking positively influences the environmental intentions of ownermanagers in Tunisia.

\section{Methodology}

According to a recent United Nations report (UNDP, 2018), the Human Development Index of Tunisia is high (0.735). In the environmental field, Tunisia participates in sustainable development programs launched by the United Nations. Tunisia is a developing country deploying significant human and technical resources for the protection of nature (Hamdoun et al., 2016). These considerations suggest that Tunisia is representative of developing countries with regard to analysis of the environmental intentions of owner-managers.

Environmental concerns are closely related to industrial activities (Martin-Pena et al., 2010). Industrial companies face significant environmental challenges (Hockerts \& Wüstenhagen, 2010). Their production processes represent ecological risk that is very damaging to the environment (Williamson et al., 2006). We choose to study the textile-clothing industry because the manufacturing industry generates significant environmental pollution (Banerjee et al., 2003). Textile production has different impacts from excessive use of water in growing cotton crops to the chemical pollutants in dyeing and finishing of fabrics. Furthermore, trends without an industry infrastructure to recycle and reuse discarded textiles (DiVito and Bohnsack, 2017). In addition, the textile-clothing industry is among the priority industries designated by the Tunisian state as part of an environmental improvement program. As such, it is important to identify owner-managers who intend to implement environmental practices with a view to rational allocation of financial incentives and public support for this program.

On the economic front, textile-clothing companies in Tunisia employ nearly one-third (31.1\%) of the total workforce of the industry (161,810 jobs) and contribute $20 \%$ of GDP. We focus on SMEs in the Sahel region where half (48\%) of all Tunisian textile-clothing companies (889 companies) are located ${ }^{1}$. The Sahel is part of eastern Tunisia, and faces crucial environmental issues owing to pollution damage caused by industrial companies.

\footnotetext{
${ }^{1}$ Data collected in March 2019 on the website of the Agency for the Promotion of Industry and Innovation (http://www.tunisieindustrie.nat.tn/fr/tissu.asp).
} 
In addition to the sectoral and geographical importance of this study, the lack of research on the factors determining environmental intention is particularly critical for SMEs. In Tunisia, SMEs are excluded from environmental research (Tounés et al., 2018; Turki, 2014). Most studies focus on large firms (Gana-Oueslati et Labaronne, 2011; Hockerts and Wüstenhagen, 2010; Jansson et al., 2017; Roxas and Coetzer, 2012) arguing their proactiveness to environmental activities (Murillo-Luna et al., 2011) and the extent of damage they cause to nature and humans (Álvarez Gil et al., 2001; Walker et al., 2014). However, SMEs dominate the business arena in many countries, face different issues and their environmental effects are more damaging to the environment than those of large firms (Gadenne et al., 2009; Jansson et al., 2017; Williamson et al., 2006).

\section{Data collection}

Researchers in the areas of SME entrepreneurship and the environment primarily target on owner-managers because they are the main decision-makers in firm strategy (Kreiser et al., 2002; Lumpkin \& Dess 2001). They play a crucial role in the development of environmental strategies (Alt et al., 2015; Aragón-Correa et al., 2008; Banerjee et al., 2003; RuedaManzanares et al., 2008; Schaltegger \& Wagner, 2011; Sharma et al., 2007). Thus, the extent to which an SME adopts environmentally friendly practices depends largely on its ownermanagers (Jansson et al., 2017; Roxas \& Coetzer, 2012). This is particularly true in the context of developing countries where environmental practices are the initiative of ownermanagers (Jamali \& Mirshak, 2007).

Based on these observations, for the survey, we select 889 owner-managers operating in the textile-clothing industry in the database of the Agence Nationale de Protection de l'Environnement (ANPE - National Agency for Environmental Protection). We carry out two filters according to the workforce and the legal independence of the companies. Thus, we remove 111 owner-managers from large companies (250 or more employees - We follow the OECD's definition of firm size based on 10-249 employees) and 277 owner-managers whose company belongs to a foreign group or multinational. The target sample consists of 501 owner-managers.

Of these, 233 owner-managers responded positively to our survey. We combine three methods of data collection according to the wishes of the owner-managers. We interviewed 
125 by telephone and 85 face to face. We submitted the questionnaire electronically to 23 owner-managers. After eliminating 7 questionnaires with missing data, the final sample of the study comprises 226 respondents.

\section{Descriptive statistics}

Table 1 contains the descriptive statistics of the SMEs surveyed, of which $60 \%$ is located in the city of Monastir. More than two-thirds (68\%) of SMEs are clothing manufacturers. This score is fairly representative of the distribution by industry of all Tunisian textile-clothing companies. More than half (55\%) of the SMEs studied have been in existence for less than 10 years. More than $80 \%$ of these SMEs each has a workforce of between 10 and 49 employees. More than $60 \%$ of the SMEs surveyed are full exporters. This statistic is similar to that for all Tunisian textile-clothing SMEs whose export turnover represents more than $80 \%$.

---Insert Table 1 about here---

According to the socio-demographic characteristics of the SME owner-managers, there is a dominant profile according to gender, age, nationality, and level of education (Table 2). The owner-managers are mostly men (87\%) and Tunisian nationals (84\%). Most are older than 40 years $(63 \%)$ and have an average level of university education $(50 \%)$.

---Insert Table 2 about here---

\section{Measurement of variables}

Dependent variable - Environmental intention (EI). We adapt the three-item Likert scale of the reasoned action theory of Ajzen and Fishbein (1980) because there is no reliable measure of this concept in the literature (Kuckertz \& Wagner, 2010). Validated in a previous study (Tounés et al., 2014) (Appendix 1), EI measures the likelihood and choice of owner-managers to adopt (or not) environmental actions. Principal component analysis indicates that EI is a unidimensional variable with high reliability (Cronbach's alpha coefficient $=0.93$ ).

Independent variables. An increasing number of studies argue for a multidimensional perspective of entrepreneurial orientation, namely, better psychometric properties and a high level of measurement accuracy of the constructs (Dess et al., 1999; Kreiser et al., 2002). The separate study of each dimension of entrepreneurial orientation reinforces the theory from a normative and descriptive viewpoint (Dess et al., 1999). In accordance with a large body of literature, we consider entrepreneurial orientation as a concept composed of three distinct 
dimensions (Dess et al., 2011; Lumpkin \& Dess, 1996, 2001; Miller \& LeBreton-Miller, 2011): innovativeness, proactiveness, and risk-taking.

The strategic posture scales developed by Covin and Slevin (1989) remain the most used in the literature to measure these dimensions with proven reliability in various studies (Kreiser et al., 2010), various countries (Kreiser et al., 2002) and environmental field (DiVito \& Bohnsack, 2017; Jansson et al., 2017). To operationalize innovativeness, proactiveness, and risk-taking in our research, we keep all the items of the strategic posture scales of Covin and Slevin (1989) and adapt them from organizational level to individual level (Appendix 1).

Innovativeness (INNOV). This concept is operationalized through a six-point Likert scale. It refers to the production and marketing of tried and tested products and services, the nature of changes to them, and research and technological development. Principal component analysis after varimax rotation indicates two factors (table 3). Recent research stream has shown that the while the Covin and Slevin scale has a relatively consistent factor structure across national boundaries, it is not invariant across these contexts. Earlier studies in different cultures and markets have demonstrated that innovativeness can have several sub-dimensions (George and Marino, 201; Morris et al., 2011).

The first factor INNOVI refers to the number of new lines of goods or services produced as well as the intensity (minor or radical) introduced into these lines of goods and services. The second factor INNOV2 provides information on the importance given by owner-managers to the production of tried and tested products or services, research and development, and technological innovations. Reliability levels of both factors have acceptable scores (Cronbach's alpha) of 0.87 and 0.76 , respectively).

Proactiveness (PROACT). Expressed using a six-item Likert scale, proactiveness refers to the imitation of competitors or the ability of owner-managers to undertake action before them, the degree of introduction of new products or services, management techniques and new technologies within their company, as well as the intensity of their competitive attitudes. The factor analysis after varimax rotation indicates two variables (table 3). The first PROACT1 refers to undertaking actions before competitors or imitating their actions as well as to competitive attitudes (or not) vis-à-vis them. The second factor PROACT2 measures the extent of the introduction of new products/services, managerial techniques and operating 
technologies. Our results identify the same two dimensions of main researches done in the field of entrepreneurial orientation (Kreiser et al., 2002). In fact, we ensure the discriminant validity of proactiveness. The reliability scores of the factors are very satisfactory $(0.83$ and 0.89 , respectively).

---Insert Table 3 about here---

Risk-taking (RISK). Owner-managers are asked upon to formulate their agreement or disagreement with these seven items operationalizing risk-taking: a high propensity for low or high-risk projects, the adoption of a prudent or bold behavior to achieve the goals set, and finally, in a situation of uncertainty, cautious or aggressive attitudes toward making financial decisions and exploiting potential entrepreneurial opportunities. The dimensionality test shows a single factor with a very good internal consistency value (Cronbach's alpha $=0.90)$.

Control variables. To consider other factors that may influence environmental intention, we place particular emphasis on socio-demographic characteristics of the owner-manager and the specifics of the industry. First, we control by GENDER, NATIONALITY, seniority in the company SENIOR, $A G E$, and level of education $E D U C$.

Specifically, and according to Gadenne, et al. (2009), we operationalize age by creating four dummy variables: $31-40$ years old $A G E 1,41-50$ years old "GE2, 51-60 years old $A G E 3$, and 61 years old and over $A G E 4$. In line with Fitzgerald et al. (2010) and Gadenne et al. (2009), we control the prediction of environmental behavior through education by distinguishing four dummy variables: no secondary school diploma EL1, secondary school diploma EL2, and tertiary degree EL3.

Second, for industrial specifics, in line with research on environmental strategy (Alt et al., 2015; Kreiser et al., 2010; Rettab et al., 2009; Sharma et al., 2007; Rueda-Manzanares et al., 2008), we include the number of employees SIZE to control the potential effect of firm size on environmental intention. In addition, it is shown that environmental pollution levels vary from one industry to another (Alt et al., 2015; Rettab et al., 2009). Five subsector dummy variables are included: fading, coloring, and printing FCP; clothing manufacturing CLOTH; weaving $W E A V$; embroidery EMBR; and spinning and finishing SPFINISH. 


\section{Hypothesis test results}

Before testing the hypotheses, we proceed to the Pearson correlation test to make sure that the data conforms to the conditions necessary for the regression analysis. As shown in Table 4, the maximum value of the correlation coefficients equals 0.65 , which is below the recommended threshold of 0.70 . In addition, we proceed to the variance inflation factor (VIF) test to detect multicollinearities between independent variables. The VIF thresholds (max $=$ 9.39) fall below 10, which is the recommended threshold of Neter et al. (1996), except for the variable CLOTH $(\mathrm{VIF}=18,004)$, which we omit to avoid the effects of multicollinearity in the analysis.

---Insert Table 4 about here---

To test the hypotheses, we perform multiple linear regression analyzes (Table 5). The first model (M1) reports all the control variables. Apart from the fading, coloring, and printing FCP subsector, which significantly influences the formation of environmental intention (Beta $=0.309, \operatorname{sig}=0.001)$, all control variables have no statistically significant influence.

The second model (M2) includes the main variables. The change in the $F$ statistics from M1 to M2 is significant, indicating that the main variables contribute significantly to the explained variance in the dependent variable ( $\mathrm{F}$ Change $=52.119 ; \mathrm{p}=0.01$ ). Indeed, the adjusted $\mathrm{R}^{2}$ increases from 0.09 to 0.59 when the main variables are included in $\mathrm{M} 2$. The value of the Fisher-Snedecor coefficient shows that this coefficient of determination is statistically significant (M2: $F=17.216$, sig $=0.001$, for 28 and 197 degrees of freedom). Therefore, we conclude that the model fit obtained by the multiple stepwise regression is satisfactory.

---Insert Table 5 about here---

The first hypothesis predicts that innovativeness positively influences the environmental intention of Tunisian' owner-managers. As can be seen in Table 5, the innovation variables INNOVI and INNOV2 contribute significantly to explaining environmental intention. The new lines of goods or services produced and marketed, the intensity of change introduced in these lines of goods and services INNOVI, and the importance given to the production of tried and tested goods or services, $\mathrm{R} \& \mathrm{D}$, and technological innovations INNOV2 have a positive 
significant influence on the environmental intentions of owner-managers (with Beta scores of 0.228 and 0.296 , respectively, sig $=0.001$ ). Thus, hypothesis 1 is supported.

The second hypothesis examines the role of proactiveness in shaping the environmental intention of owner-managers in Tunisia. As shown in Table 5, only PROACT1 relative to undertaking actions before competitors or imitating their actions and the manifestation of competitive attitudes in their regard significantly and positively influence owner-managers' intention to behave in an environmentally responsible way $($ Beta $=0.226$, sig $=0.001)$. The introduction of new products/services, managerial techniques, and operating technologies PROACT2 does not seem to determine the environmental intention of the owner-managers (Beta $=0.027$ not significant). Thus, hypothesis 2 is partially supported.

Our third hypothesis posits the positive impact of risk-taking on the environmental intention of Tunisian owners-managers. Our results indicate that a propensity for high-risk projects, the adoption of bold and large-scale behavior, and aggressive attitudes to exploit potential opportunities significantly explain the formation of the environmental intention of ownermanagers $($ Beta $=0,105 ; \operatorname{sig}=0.05)$. Thus, hypothesis 3 is supported.

\section{Discussion}

The purpose of this study was to analyze the contribution of entrepreneurial orientation to the formation of the environmental intention of SME owner-managers in the Tunisian textileclothing industry. While the idea that entrepreneurial orientation lead to increased commitment towards environment has received empirical support in previous research and different areas in the world (Jansson et al., 2017), whether in developed countries like France, Spain and Sweden (Courrent et al., 2016; Ayuso and Navarrete-Báez, 2018; Jansson et al., 2017), or developing countries such as Mexico (Ayuso and Navarrete-Báez; 2018), our study brings forth conceptual arguments and empirical evidence about how entrepreneurial orientation influences the formation of the environmental intention of owner-managers in developing country context. The main result of our study is that the three components of entrepreneurial orientation (innovativeness, proactiveness and risk-taking) seem to contribute to the environmentally friendly intention of the owner-managers in textile-clothing industry in Tunisia. However, the impact of each component on environmental intention seems to vary.

Indeed, further analysis of our empirical data demonstrates that the three components of entrepreneurial orientation drive environmental intention in different degrees. First, among 
the dimensions of entrepreneurial orientation, innovativeness seems to be the factor, which has the strongest impact on the environmental intention of owner-managers in Tunisia in our study. The new lines of goods or services produced and marketed, the intensity of change introduced in these lines, the importance given to the production of tried and tested goods or services, $R \& D$, and technological innovations significantly influence the environmental intentions of owner-managers in our study. Second, proactiveness has a mixed effect on the environmentally friendly intention of the owner-managers. Proactiveness, i.e. initiation of actions before competitors and the adoption of competitive attitudes toward them, seems to positively influence environmental intention of the owner-managers. On the contrary, introducing new products/services, new management techniques, and new operating technologies within the company - as second component of our proactiveness construct- does not seem to influence environmental intention of the studied owner-managers. Third, the impact of risk-taking on the environmental intention of Tunisian owner-managers takes shape through the propensity for high-risk projects (with high rates of return), and adoption of bold behavior and aggressive attitudes to exploit potential opportunities in our study. Next, we discuss the role of these three components of entrepreneurial orientation in explaining environmental intention in more details.

First, our results on the effect of innovativeness on the environmentally friendly intention of owner-managers is in conform with the earlier results of Spence et al. (2011). This result indicates that owner-managers wanting to engage in sustainable development are oriented towards innovation. Similarly, our findings corroborate with those of Hamdoun et al. (2016) in Tunisian industrial firms. These authors note that owner-managers respond to environmental issues by developing innovative strategies. As such, our study confirms the results of research carried out in developed countries on the positive impact of innovation on the environmental commitment of owner-managers (Kuckertz \& Wagner, 2010; Larson, 2000; Schaltegger \& Wagner, 2011). However, the impact of innovativeness of Tunisian owner-managers in the field of the environment must be discussed in terms of the forms it takes. Ben Boubaker-Gherib et al. (2009) argue that Tunisian owner-managers implement mostly marginal innovations of short duration to the detriment of incremental environmental innovations. This is facilitated by public incentives that favor more tangible short-term actions. Incremental and radical innovations in the field of the environment are difficult to implement because they imply significant investments and resources that Tunisian SMEs do not have (Depret \& Hamdouch, 2009; Hamdoun et al., 2016). 
Second, our findings about the positive impact of proactiveness, i,e. initiation of actions before competitors and adoption of competitive attitudes toward them, on environmental intention of Tunisian' owner-managers should be qualified by those of other researchers in Tunisia. Amara and Bensebaâ (2009) conclude that owner-managers in the textile-clothing industry adopt behaviors that are sometimes proactive and sometimes reactive in interaction with stakeholders. Contrary to our findings, Gherib and Ghozzi-Nékhili (2012), Turki (2013), and more recently the research Hamdoun et al. (2016) in Tunisian industry find that environmental commitment is not correlated with the proactiveness of owner-managers. The owner-managers adopt defensive environmental strategies limited to coercive regulation texts and devices for fear of penalties. The contradicting result of our research with earlier empirical studies can be explained by the fact that the owner-manager of our sample are specialized in very competitive sector, namely textile-clothing that require proactive and aggressive managers (Perotti-Reille, 2008).

Our non-significant finding of the second component of proactiveness, i.e. introduction of new products/services, managerial techniques and operating technologies is in line with some earlier studies. For example, GIZ (2012) demonstrated a lack of the renewal of managerial techniques of Tunisian' owner-managers in the field of the environment. The managerial approach of Tunisian owner-managers is more akin to compliance with regulations and to taking advantage of public incentives, as accentuated by the scarcity of Tunisian skills in the field of the environment (Toumi, 2013). In similar fashion, integrating new operating technologies into the environment can deter owner-managers from being proactive because these technologies represent a significant cost (Murillo-Luna et al., 2011). Tunisian ownermanagers do not seem appear to be proactive in the environment when the cost represents a significant burden that cannot be met by sufficient resources. In developing countries (Oreg \& Katz-Gerro, 2006; Özen \& Küskü, 2009), and particularly in Tunisia (Turki, 2013), the implementation of environmental practices is particularly influenced by resource conditions, which should be considered at a high level.

Third, the propensity for high-risk projects (with high rates of return), and adoption of bold behavior and aggressive attitudes to exploit potential opportunities seem to influence environmental intentions of Tunisian owner-managers. This might be due to the postrevolutionary period in Tunisiam which has been marked by an institutional vacuum in the environmental field (Koleva and Gherib, 2012; Turki, 2014), which, in turn, has probably 
accentuated uncertainty in the textile-clothing industry. This situation has heightened risktaking by owner-managers to engage in environmental practices (Turki, 2014). Confronted with growing hostility in the political and economic environment, Tunisian owner-managers tend to accept risk (El Akremi et al., 2007). This result in the post-revolutionary context contrasts with those of developed countries. While it is in line with research carried out in France (Courrent et al., 2016), it is contrary to the result of Pedersen (2010), indicating that owner-managers in various industries avoid risk and prefer to confine themselves to imitation strategies.

Finally, the examination of the effect of the control variables on the environmental intention of Tunisian owner-managers indicates reduced utility of model 1. Indeed, only the fading, coloring, and printing wash FCP activity significantly influences environmental intention in our study. This result is expected, because this subsector, considered as the most polluting of the five subsectors, is subject in Tunisia to strict regulation and increased public control of liquid, solid waste, and air emissions compared to other subsectors in the textile-clothing industry.

\section{Conclusion}

Our research contributes to knowledge by mobilizing the concept of entrepreneurial orientation to study the environmental intention of owner-managers. Despite considerable progress of environmental psychology in studying the factors determining the intention to adopt pro-environmental behavior (Bamberg \& Möser, 2007), the relationship between entrepreneurial orientation and environmental intention is rarely examined in the literature. By deploying key concepts of entrepreneurship to explain environmental intention (Kuckertz \& Wagner, 2010; York \& Venkataraman, 2010), our results suggest that the concept of entrepreneurial orientation, i.e. innovativeness, proactiveness, and risk-taking, can be considered in an integrative perspective with dominant theories in the field of environment (ie. Theory of planned behavior, stakeholder theory and theory of resource dependence) to explain the environmental intention of owner-managers.

Our research offers a unique terrain for understanding environmental intention in the context of a developing country, Tunisia, given that developing countries in the research mainstream broadens knowledge in an uncertain context and high risk characterizing the economies of these countries. 
For practitioners, environmental concerns represent entrepreneurial opportunities in the apparel/textile industry to make substantial changes to processes and routines (DiVito and Bohnsack, 2017). A better understanding of environmental intention indicates encouragement of the entrepreneurial orientation of owner-managers in favor of the sustainable environment. This is particularly important because public systems of control and enforcement of environmental regulations have a limited and ineffective effect on the environmental behavior of managers in developing countries (Jamali \& Mirshak, 2007, Özen \& Küskü, 2009; Rettab et al., 2009), particularly in Tunisia (Toumi, 2012; Turki, 2013).

It is desirable in the textile-clothing industry to coherently integrate environmental and innovative policies to strengthen the environmental performance of Tunisian companies. One way to do this is to encourage SME owner-managers to implement preventive rather than curative environmental innovations. For Tunisian owner-managers to constrain themselves to meet the normative and coercive pressures of different stakeholders (Koleva \& Gherib, 2012; Turki 2012), they need to develop innovative and proactive strategies that reconcile environmental and economic interests.

The international textile-clothing market is constantly experiencing important changes in innovation processes (Perotti-Reille, 2008). To support the economic competitiveness of Tunisian textile-clothing owner-managers through environmental innovations, it is necessary to provide information resources and advice on the evolution of markets in terms of consumption, regulation, and technology. This support remains modest in many developing markets (Jamali \& Mirshak, 2007; Roxas \& Coetzer, 2012) and Tunisia in particular (Labaronne \& Oueslati-Gana, 2011). The perceived usefulness of this kind of information contributes to the implementation of environmental practices (Garay et al., 2017).

Our results should be treated with caution owing to three limitations. First, we provide theoretical and empirical evidence on the links between entrepreneurial orientation and environmental intention, but do not capture what triggers environmental behavior. The temporal instability of environmental intention (Lokhorst et al., 2013) conditions the passage to the act (Kuckertz \&Wagner, 2010).

Second, our research highlights only the individual level of predicting environmental intention. However, three levels are to be considered interdependently in predicting 
environmental behavior: individual, organizational, and contextual levels. Generally, environmental intention is best studied when it is perceived as a combination of self-interest and consideration of different stakeholders (Alt et al., 2015; Hing Lo et al., 2012). The environmental proactiveness and innovativeness of companies depends on managers' perceptions of the importance of different environmental, social, and economic stakeholders (Gadenne et al., 2009; Gana-Oueslati \& Labaronne, 2011; Jansson et al., 2017; RuedaManzanares et al., 2008). Third, in reference to Hart's (1995) theory of resource dependence, we do not consider the resources and capacity of leaders to study environmental intention (Rueda-Manzanares et al., 2008).

This study suggests promising future research directions. If our results are valid in Tunisia, then developing countries should not be considered as a uniform block (Bruton et al., 2008). This study can be replicated in different developing countries taking into account differences in their histories, economies, culture, and institutional developments. There are significant differences in risk-taking and proactiveness across countries depending on the institutional environment and economic and political risks (Dess et al., 2011; Kreiser et al., 2010; Roxas \& Coetzer, 2012; Slevin \& Terjesen, 2011), inducing a variety of environmental behavior (Özen \& Küskü, 2009; Rettab et al., 2009).

For obvious reasons of homogeneity of the interviewed population, the links highlighted between the entrepreneurial orientation and environmental intention are appropriate for the industry analyzed in this study. It would be appropriate to explore other industries with high environmental impacts to differentiate the effect of entrepreneurial orientation on the environmental intention of owner-managers. 


\section{References}

Ajzen, I. \& Fishbein, M. (1980). Understanding attitudes and predicting social behavior, Englewood Cliffs, NJ, Prentice Hall.

Ajzen, I. (1991). The Theory of Planned Behaviour, Organizational Behaviour and Human Decision Process, 50, 179-211.

Alt, E, Diez-de-Castro, E. P, Lloréns-Montes, F. J. (2015). Linking Employee Stakeholders to Environmental Performance: The Role of Proactive Environmental Strategies and Shared Vision. Journal of Business Ethics, 128, 67-181.

Amara, A., \& Bensebaa, F. (2009). La mise en œuvre des pratiques socialement responsables: entre déterminisme et comportements proactifs, Revue Management et Avenir, 25, 1535.

Aragón-Correa, J. A. (1998). Strategic proactivity and firm approach to the natural environment, Academy of Management Journal, 4(5), 556-567.

Aragón-Correa, A., \& Sharma, S. (2003). A contingent resource-based view of proactive corporate environmental strategy. Academy of Management Review, 28(1), 71-88.

Ayuso, S., \& Navarrete-Báez, F. E. (2018). How Does Entrepreneurial and International Orientation Influence SMEs' Commitment to Sustainable Development? Empirical Evidence from Spain and Mexico, Corporate Social Responsibility and Environmental Management, 25, p. 80-94.

Baker, W. E., \& Sinkula, J. M. (2009). The complementary effects of market orientation and entrepreneurial orientation on profitability in small businesses, Journal of Small Business Management, 47(4), p. 443-464.

Bamberg, S., \& Möser, G. (2007). Twenty years after Hines, Hungerford, and Tomera: A new meta-analysis of psycho-social determinants of pro-environmental behavior. Journal of Environmental Psychology, 27, p. 14-25.

Banerjee, S.B., Iyer S.E, \& Kashyap, R.K. (2003). Corporate Environmentalism: Antecedents and Influence of Industry Type. Journal of Marketing, 67, 106-122.

Bansal, P., \& Roth, K. (2000). Why companies do green: a model of ecological responsiveness. Academy of Management journal, 43(4), 717-736.

Bansal, P., Gao J, K., \& Qureshi I. (2014). The Extensiveness of Corporate Social and Environmental Commitment across Firms over Time. Organization Studies, 35(7), 949966.

Ben Boubaker Gherib, J., Spence, M. \& Ondoua Biwolé, V. (2009). Développement durable et PME dans les pays émergents : Entre proactivité, opportunisme et compromis. Journal of Small Business and Entrepreneurship, 22(3), 275-295.

Boso, N., Story, V. M. \& Cadogan, J. W. (2013). Entrepreneurial orientation, market orientation, network ties, and performance: Study of entrepreneurial firms in a developing economy, Journal of Business Venturing, 28, 708-727.

Brulhart, F. \& Gherra, S. (2015). Stratégie environnementale proactive, compétences naturelles, et performance économique : une approche par la théorie des ressources et compétences, Management International, 20(1), 94-113.

Bruton, G. D., Ahlstrom, D. \& Obloj K (2008). Entrepreneurship in emerging economies: where are we today and where should the research go in the future. Entrepreneurship Theory and Practice, 1-14.

Cai, L, Cui, J. \& Jo. H (2016). Corporate Environmental Responsibility and Firm Risk, Journal of Business Ethics, 563-594.

Courrent, J-M., Chasse, S. \& Waleed O (2016). Do Entrepreneurial SMEs Perform Better Because They are More Responsible? Journal of Business Ethics, 138, 1-20.

Covin, J. G. \& Slevin, D. P. (1989). Strategic management of small firms in hostile and benign environments. Strategic Management Journal, 10, 75-87. 
Covin, J. G. \& Slevin, D. P. (1991). A conceptual model of entrepreneurship as firm behavior. Entrepreneurship Theory and Practice, 16 (1), 7-25.

Covin, J. G. \& Lumpkin, G. T. (2011). Entrepreneurial orientation theory and research reflections on a needed construct. Entrepreneurship Theory and Practice, 35 (5), 855872.

de Guimarães., J. C. F., Severo E. A. \& de Vasconcelos, C. R. M. (2018). The influence of entrepreneurial, market, knowledge management orientations on cleaner production and the sustainable competitive advantage Journal of Cleaner Production, 174, p. 1653-1663

Dess, G. G., Lumpkin, G. T. \& McGee, J. E. (1999). Linking corporate entrepreneurship to strategy, structure, and process: Suggested research directions. Entrepreneurship Theory and Practice, 23(3), 85-102.

Dess, G. G, Pinkham B. C. \& Yang H (2011). Entrepreneurial Orientation: Assessing the construct's validity and addressing some of its implications for research in the areas of family business and organizational learning. Entrepreneurship Theory and Practice, 35(5), 1077-1089.

DiVito, L. \& Bohnsack, R. (2017). Entrepreneurial orientation and its effect on sustainability decision tradeoffs: The case of sustainable fashion firms, Journal of Business Venturing, 32, 569-587.

El Akremi, A., Ikram Nasr, M. \& Sassi, N. (2007). Impact de la culture nationale sur la confiance interpersonnelle en milieu du travail : Analyse comparative entre la France et la Tunisie. 18ème Congrès annuel de l'Association francophone de Gestion des Ressources Humaines (AGRH), 19-20 September, Fribourg (Switzerland).

Fisher, K., Geenen, J., Jurcevic, M., McClintock, K. \& Davis, G. (2009). Applying assetbased community development as a strategy for CSR: A Canadian perspective on a win-win for stakeholders and SMEs. Business Ethics: A European Review, 18(1), 6682.

Gadenne, D. L., Kennedy, J., \& McKeiver, C. (2009). An empirical study of environmental awareness and practices in SMEs. Journal of Business Ethics, 84, p. 45-63.

Gana-Oueslati, E. \& Labaronne D (2011). Corporate social responsibility, managerial entrenchment and privatization. Example of an Algerian public company management. Management International. 15(4), p. 37-47.

Garay, L., Fonte, X. \& Pereira-Moliner, J. (2017). Understanding sustainability behaviour: The relationship between information acquisition, proactivity and performance, Tourism Management, 60, p. 418-429.

George, B. A. \& Marino, L. (2011). The Epistemology of Entrepreneurial Orientation: Conceptual Formation, Modeling, and Operationalization. Entrepreneurship Theory and Practice, 35 (5), 989-1024.

Hall J. K, Gregory A, Daneke G. A. \&Lenox M. J. (2010). Sustainable development and entrepreneurship: Past contributions and future directions. Journal of Business Venturing. 25, p. 439-448.

Hart, S. L. (1995). A natural-resource based view of the firm. Academy of Management Review, 20(4), 986-1014.

Hing Lo, S., Gjalt-Jorn Y. P. \& Gerjo Kok, G. (2012). A Review of Determinants of and Interventions for Proenvironmental Behaviors in Organizations. Journal of Applied Social Psychology, 4(12), 2933-2967.

Hockerts, K, \& Wüstenhagen R (2010). Greening Goliaths versus emerging Davids Theorizing about the role of incumbents and new entrants in sustainable entrepreneurship, Journal of Business Venturing, 25, 481-492

Jamali, D. \& Mirshak, R. (2007). Corporate Social Responsibility (CSR): Theory and Practice in a Developing Country Context. Journal of Business Ethics, 72, 243-262 
Jansson, J., Nilsson, J., Modig, F \& Hed Vall, G. (2017). Commitment to Sustainability in Small and Medium-Sized Enterprises: The Influence of Strategic Orientations and Management Values, Business Strategy and the Environment, 26(1), p. 69-83.

Kreiser, P. M., Marino, L. D. \& Weaver, K. M. (2002). Assessing the psychometric properties of the entrepreneurial orientation scale: A multi-country analysis. Entrepreneurship Theory and Practice, 26, 71-94.

Kreiser, P. M., Marino, L. D., Dickson P. \& Weaver K. M (2010). Cultural influences on entrepreneurial orientation: The impact of national culture on risk taking and proactiveness in SMEs. Entrepreneurship theory and practice, p. 959-983.

Kuckertz, A. \& Wagner, M. (2010), "The influence of sustainability orientation on entrepreneurial intentions - Investigating the role of business experience". Journal of Business Venturing, 25(5), 524-539.

Labaronne, D. \& Gana-Oueslati, E. (2011). Analyse comparative Maroc-Tunisie du cadre institutionnel de la RSE dans les PME. Management et Avenir, 43, 103-121.

Larson A. L (2000). Sustainable innovation through an entrepreneurship lens. Business Strategy and the Environment, 9, 304-317.

Lokhorst, A. M., Werner, C., Staats, H, Van Dijk, E. \& Gale, J. L. (2013), Commitment and behavior change: A meta-analysis and critical review of commitment-making strategies in environmental research. Environment and Behavior, 45(1), 3-34.

Lumpkin, G. T. et Dess, G. G. (1996), Clarifying the entrepreneurial orientation construct and linking it to performance. Academy of Management Review, 21(1), 135-172.

Lumpkin, G. T. \& Dess, G. G., (2001). Linking two dimensions of entrepreneurial orientation to firm performance. Journal of Business Venturing, 16, 429-451.

Lumpkin, G. T., Brigham, K. H. \& Moss T. W (2010). Long-term orientation: Implications for the entrepreneurial orientation and performance of family businesses. Entrepreneurship and Regional Development, 22(3-4), 241-264.

Madsen, E. L. (2007). The significance of sustained entrepreneurial orientation on performance of firms: a longitudinal analysis. Entrepreneurship and Regional Development, 191, 185-204.

Miller, D. (1983). The correlates of entrepreneurship in three types of firms. Management Science, 29(7), 770-791.

Miller, D. \& LeBreton-Miller, I. (2011). Governance, social identity, and entrepreneurial orientation in closely held public companies. Entrepreneurship Theory and Practice, 35(5), 1051-1076.

Michael H. Morris, M. H., Webb, J. W. \& Franklin, R. J. (2011). Understanding the Manifestation of Entrepreneurial Orientation in the Nonprofit Context, Entrepreneurship Theory and Practice, 35(5), 947-971.

Murillo-Luna, J. L., Garcés-Ayerbeb, C. \& Rivera-Torres., P. (2011). Barriers to the adoption of proactive environmental strategies, Journal of Cleaner Production, 19, . 1417-1425

Neter, J., Kutner, M.H., Wasserman, W. \& Nachtsheim, C.J. (1996). Applied Linear Statistical Models, 4ème edition, McGraw-Hill, New York, NY.

Özen, S. \& küskü, F. (2009). Corporate environmental citizenship variation in developing countries: An institutional framework, Journal of Business Ethics, 89, 297-313.

Pedersen, E.R. (2010). Modelling CSR: how managers understand the responsibilities of business towards society. Journal of Business Ethics, 91(2), 155-166.

Pinget, A., Bocquet, R. \& Mothe, C. (2015). Barriers to Environmental Innovation in SMEs: Empirical Evidence from French Firms, M@n@gement, 18(2), p. 132-155.

Rettab, B., Ben Brik, A. \& Mellahi, K. (2009). A Study of management perceptions of the impact of corporate social responsibility on organizational performance in emerging economies: The Case of Dubai. Journal of Business Ethics, 89, 371-390. 
Rodríguez-Barreiro, L. M., Fernández-Manzanal, R., Serra, L. M., Carrasquer, J., Murillo, M. B, Morales, M. J., Calvo J. M \& del Valle, J. (2013). Approach to a causal model between attitudes and environmental behaviour. A graduate case study. Journal of Cleaner Production, 48, 116-125.

Roxas, B. \& Coetzer, A. (2012). Institutional Environment, Managerial Attitudes and Environmental Sustainability Orientation of Small Firms. Journal of Business Ethics, 111, 461-476.

Rueda-Manzanares, A., Aragón-Correa, J. A. \& Sharma, S. (2008). The Influence of Stakeholders on the Environmental Strategy of Service Firms: The Moderating Effects of Complexity, Uncertainty and Munificence,. British Journal of Management, 19, 185203

Sambasivan, M., Bah, S. M. \&Ann, H. J. (2013). Making the case for operating "Green": impact of environmental proactivity on multiple performance outcomes of Malaysian firms. Journal of Cleaner Production, 42, 69-82.

Schaltegger, S. \& Wagner, M. (2011). Sustainable Entrepreneurship and Sustainability Innovation: Categories and Interactions. Business Strategy and the Environment, 20, 222-237.

Sharma, S., Aragón-Correa, J. A. \& Rueda-Manzanares, A. (2007). The contingent influence of organizational capabilities on proactive environmental strategy in the service sector: An analysis of North American and European ski resorts. Canadian Journal of Administrative Sciences, 24, 268-283.

Shepherd, D.A., Patzelt, H., 2011. The new field of sustainable entrepreneurship: studying entrepreneurial action linking "what is to be sustained" with "what is to be developed", Entrepreneurship Theory and Practice. 35(1), p. 137-163.

Simpson, M., Taylor, N. \& Barker, K. (2004). Environmental responsibility in SMEs: Does it deliver competitive advantage? Business Strategy and the Environment, 13(3), 156-171.

Slevin, D. P. \& Terjesen, S. A. (2011). Entrepreneurial orientation: reviewing three papers and implications for further theoretical and methodological development. Entrepreneurship Theory and Practice, 35(5), 973-987.

Spence, M., Ben Boubaker Gherib., J. \& Ondou Biwolé, V. (2011). Sustainable Entrepreneurship: Is Entrepreneurial will Enough? A North-South Comparison. Journal of Business Ethics, 99(3), 335-367.

Tounés, A., Tornikoski, E. T. \& Gribaa, F. (2018). The formation of environmentally friendly intentions of SME owners-managers in emerging country context: the case of Tunisian's textile-clothing industry. Organization \& Environment.

Tounés, A., Gribaa, F. \& Messeghem, K. (2014). L'intention environnementale des dirigeants de PME: une étude exploratoire dans l'industrie du textile-habillement", Revue Internationale PME, 27(1), 125-152.

Turki, A. (2014). Les PME face à la RSE : une étude de leurs comportements dans le contexte tunisien post-révolution. la Revue des Sciences de Gestion, Direction et Gestion, 269270, 161-169.

Walker, K., Ni, N \& Huo, W. (2014). Is the red dragon green? An examination of the antecedents and consequences of environmental proactivity in China. Journal of Business Ethics, 125, 27-43.

Williamson, D., Lynch-Wood, G. \& Ramsay, J. (2006). Drivers of environmental behavior in manufacturing SMEs and the implications for CSR. Journal of Business Ethics, 67, $317-$ 330.

York, J. C. \& Venkataraman, S. (2010). The entrepreneur-environement nexus: Uncertainty innovation, and allocation. Journal of Business Venturing, 25, 449-463. 
Zhao, M., Tan, J. \& Park, S H (2014). From Voids to Sophistication: Institutional Environment and MNC CSR Crisis in Emerging Markets. Journal of Business Ethics, $122,655-674$. 


\section{Appendix 1 - Main Variables and Their Items}

\section{Environmental Intention (EI).}

In the next 5 years, what is the likelihood that $(1=$ very low, $6=$ very high $)$

1. You will undertake an environmental measures or policies

2. You will not undertake an environmental measures or policies

3 . In the next 5 years, if you would to choose between undertaking environmental measures or policies and their abandonment, what would you prefer? $(1=$ certainly abandon, $6=$ certainly undertake

\section{Innovativeness}

In general, I favor a strong emphasis on $(1=$ Not agree at all, $6=$ completely agree $)$

1. The production of tried and true products or services

2. R\&D, technological leadership and innovation

3. Very many new lines of products or services produced/marketed

4. No new lines of products or services produced/marketed

5. Changes you introduced in products or services lines have been mostly of minor nature

6 . Changes you introduced in products or services lines have usually been of radical

\section{Proactivenesss}

In dealing with my competitors $(1=$ Not agree at all, $6=$ completely agree $)$,

1. I typically respond to actions which competitors initiate

2. Initiate actions which competitors then respond to

3. I'm very seldom the first to introduce new products/services, administrative techniques, operating technologies,

4. I'm very often the first business to introduce new products/services, administrative techniques, operating technologies

5. I typically seek to avoid competitive clashes preferring a "live-and-let-live".

6. I typically adopt a very competitive "undo-the-competitors" posture.

\section{$\underline{\text { Risk-taking }}$}

In general, I have a strong proclivity for $(1=$ Not agree at all, $6=$ completely agree $)$,

1. low-risk projects (with normal and certain rates of return)

2. high-risk projects (with chances of very high returns)

In general, I believe that owning to the nature of the environment

4. It is best to explore it gradually via timid, incremental behavior

5. Bold, wide-ranging acts are necessary to achieve the firm's objectives

When confronted with decision-making situations involving uncertainty, I typically adopt ( 1 $=$ Not agree at all, $6=$ completely agree),

6. a cautious, "wait-and-see' posture in order to minimize the probability of making costly decisions

7. a bold, aggressive posture in order to maximize the probability of exploiting potential opportunities. 
Table 1 - Sociodemographic characteristics of the SMEs.

\begin{tabular}{|c|c|c|c|}
\hline & & Frequency & Percentage \\
\hline \multirow[t]{3}{*}{ City } & Monastir & 136 & 60 \\
\hline & Sousse & 64 & 28 \\
\hline & Mahdia & 26 & 12 \\
\hline \multirow[t]{6}{*}{ Branch of activity } & Clothing manufacturing & 154 & 68 \\
\hline & Fading, coloring and printing & 27 & 12 \\
\hline & Weaving & 22 & 10 \\
\hline & Embroidery & 12 & 5 \\
\hline & Spinning and finishing & 9 & 4 \\
\hline & Finishing & 2 & 1 \\
\hline \multirow{6}{*}{$\begin{array}{l}\text { Date of Business } \\
\text { Start up or corporate } \\
\text { recovery }\end{array}$} & Less than 2 years ago & 19 & 8 \\
\hline & 2 to less than 4 years ago & 18 & 8 \\
\hline & 4 to less than 6 years ago & 35 & 16 \\
\hline & 6 to less than 8 years ago & 32 & 14 \\
\hline & 8 to less than 10 years ago & 20 & 9 \\
\hline & 10 years ago and more & 102 & 45 \\
\hline \multirow[t]{3}{*}{ Workforce } & $10-19$ & 106 & 47 \\
\hline & $20-49$ & 68 & 30 \\
\hline & $50-249$ & 34 & 15 \\
\hline \multirow{5}{*}{$\begin{array}{l}\text { Percentage of export } \\
\text { turnover in relation } \\
\text { to global turnover }\end{array}$} & $0 \%-25 \%$ & 69 & 30.5 \\
\hline & $25 \%-50 \%$ & 3 & 1.3 \\
\hline & $50-75 \%$ & 11 & 4.9 \\
\hline & $75 \%-100 \%$ & 5 & 2.2 \\
\hline & $100 \%$ & 138 & 61.1 \\
\hline
\end{tabular}

Table 2 - Socio-demographic characteristics of the respondents.

\begin{tabular}{|llcc|}
\hline Gender & & Frequency & Percentage \\
& Male & 197 & 87 \\
& Female & 29 & 13 \\
\hline Age & Under 30 years old & 26 & 11 \\
& 31 to 40 years old & 59 & 26 \\
& 41 to 50 years old & 69 & 31 \\
& 51 to 60 years old & 54 & 24 \\
& 61years old and over & 18 & 8 \\
\hline Nationality & Tunisian & 190 & 84 \\
& Foreigner & 36 & 16 \\
\hline & Undergraduate and more & 113 & 50 \\
& College and diploma college level & 83 & 37 \\
& Technical college & 19 & 8 \\
& Primary school & 11 & 5 \\
\hline
\end{tabular}


Table 3 - Results of the principal-components with varimax rotation

Items

INNOV1

INNOV2

- The production of tried and true products or services

- R\&D, technological leadership and innovation

- No new lines of products or services produced/marketed

- Very many new lines of products or services produced/marketed

- Changes you introduced in products or services lines have been mostly of minor nature

.870

- Changes you introduced in products or services lines have usually been of radical nature

- I typically respond to actions which competitors initiate PROACT1

PROACT2

- I Initiate actions which competitors then respond to

- I'm very seldom the first to introduce new products/services,

administrative techniques, operating technologies,

- I'm very often the first business to introduce new products/services, administrative techniques, operating technologies

- I typically seek to avoid competitive clashes preferring a "live-and-let-live".

- I typically adopt a very competitive "undo-the-competitors" posture. 
Table 4. Correlation and descriptive statistics

\begin{tabular}{|c|c|c|c|c|c|c|c|c|c|c|c|c|c|c|c|c|c|c|c|c|c|c|c|}
\hline & $\bar{M}$ & $\mathrm{SD}$ & (1) & (2) & (3) & (4) & (5) & (6) & (7) & (8) & (9) & $(10)$ & (11) & (12) & (13) & (14) & (15) & (16) & (17) & $(18)$ & (19) & $(20)$ & $(21)$ \\
\hline EI (1) & 3.80 & 1.49 & 1 & & & & & & & & & & & & & & & & & & & & \\
\hline GENDER (2) & .87 & .33 & .011 & 1 & & & & & & & & & & & & & & & & & & & \\
\hline NATIONALITY (3) & .84 & .367 & .094 & $.158^{*}$ & 1 & & & & & & & & & & & & & & & & & & \\
\hline SENIOR (4) & 4.19 & 1.655 & -.087 & $-.163^{*}$ & -.115 & 1 & & & & & & & & & & & & & & & & & \\
\hline AGE & 43.9 & 10.89 & & & & & & & & & & & & & & & & & & & & & \\
\hline AGE1 (5) & .115 & .31 & .057 & $.164^{*}$ & .017 & $-.354^{* *}$ & 1 & & & & & & & & & & & & & & & & \\
\hline AGE2 (6) & .261 & .44 & -.005 & -.082 & -.052 & .129 & $-.394^{* *}$ & 1 & & & & & & & & & & & & & & & \\
\hline AGE3 (7) & .305 & .46 & -.048 & -.091 & .040 & $.408^{* *}$ & $-.333^{* *}$ & $-.371^{* * 4}$ & 1 & & & & & & & & & & & & & & \\
\hline AGE4 (8) & .238 & .238 & -.073 & -.113 & -.128 & $.264^{* *}$ & $-.175^{* *}$ & $-.195^{* *}$ & $-.165^{*}$ & 1 & & & & & & & & & & & & & \\
\hline EDUC1 (9) & .500 & .501 & .068 & -.087 & -.042 & -.025 & -.041 & .073 & -.030 & .009 & 1 & & & & & & & & & & & & \\
\hline EDUC2 (10) & .367 & .483 & .010 & -.042 & -.077 & .082 & -.113 & .059 & .052 & .084 & $-.171^{*}$ & 1 & & & & & & & & & & & \\
\hline EDUC3 (11) & .048 & .215 & .041 & $.146^{*}$ & $.145^{*}$ & $-.166^{*}$ & $.232^{* *}$ & -.106 & -.125 & $-.131^{*}$ & $-.226^{* *}$ & $-.636^{* *}$ & 1 & & & & & & & & & & \\
\hline SIZE (12) & 67.3 & 47.79 & -.039 & .037 & -.028 & $.132^{*}$ & $-.154^{*}$ & .015 & .043 & .048 & -.047 & \begin{tabular}{|l|}
-.048 \\
\end{tabular} & .090 & 1 & & & & & & & & & \\
\hline FCP (13) & .12 & .32 & $.321^{* *}$ & -.019 & $.138^{*}$ & -.033 & .030 & -.037 & .018 & -.108 & .043 & -.023 & .041 & .128 & 1 & & & & & & & & \\
\hline WEAV (14) & .10 & .29 & .049 & -.037 & $-.143^{*}$ & .062 & -.059 & .042 & -.044 & $.179^{* *}$ & -.005 & .125 & $-.149^{*}$ & -.100 & -.121 & 1 & & & & & & & \\
\hline EMBR (15) & .29 & .22 & -.117 & .027 & .005 & -.015 & .039 & .100 & -.086 & .003 & .038 & .068 & $\begin{array}{l}.079 \\
\end{array}$ & $\begin{array}{l}-090 \\
\end{array}$ & -.087 & -.078 & 1 & & & & & & \\
\hline SPFINISH (16) & .29 & .21 & -.105 & -.073 & -.083 & .080 & -.114 & -.075 & $.173^{* *}$ & .032 & .068 & .005 & -.096 & \begin{tabular}{l|l|}
-.070 \\
\end{tabular} & -.071 & $\begin{array}{ll}-.063 \\
\end{array}$ & -.045 & 1 & & & & & \\
\hline INNOV1 (17) & 3.603 & 1.400 & $.515^{* *}$ & .096 & .018 & -.046 & -.088 & -.027 & .038 & .007 & -.045 & -.042 & .040 & .060 & .097 & $\begin{array}{ll}-.022 \\
\end{array}$ & $-.170^{*}$ & -.067 & 1 & & & & \\
\hline INNOV2 (18) & 3.427 & .555 & $.626^{* *}$ & .031 & -.036 & .035 & -.007 & -.046 & .031 & -.060 & .026 & -.081 & .129 & .081 & $.182^{* *}$ & -.025 & $-.145^{*}$ & -.074 & $.401^{* *}$ & 1 & & & \\
\hline PROACT1 (19) & 3.369 & 1.155 & $.650^{* *}$ & -.052 & -.029 & \begin{tabular}{l|l|}
-.029 \\
\end{tabular} & -.008 & -.003 & -.028 & -.044 & .078 & -.111 & .067 & \begin{tabular}{l|l|}
.019 \\
\end{tabular} & $.242^{* *}$ & \begin{tabular}{l|}
-.079 \\
\end{tabular} & $-.179^{* * *}$ & -.067 & $.488^{* *}$ & $.642^{* *}$ & 1 & & \\
\hline PROACT2 (20) & 3.097 & 1.500 & $.368^{* *}$ & -.080 & -.103 & -.056 & .038 & -.011 & .059 & $-.161^{*}$ & .056 & .003 & -.038 & .051 & $.262^{* *}$ & .119 & \begin{tabular}{l|}
-.092 \\
\end{tabular} & .043 & $.159^{*}$ & $.320^{* *}$ & $.398^{* *}$ & 1 & \\
\hline RISK (21) & 3.214 & 1.149 & $.465^{* *}$ & -.018 & -.022 & .032 & -.074 & .024 & .116 & -.098 & -.011 & .049 & -.089 & \begin{tabular}{l|l|}
.013 \\
\end{tabular} & .120 & .109 & \begin{tabular}{|c|}
-.096 \\
\end{tabular} & -.063 & $.397^{* *}$ & $.406^{* *}$ & $.447^{* *}$ & $.383^{* *}$ & \\
\hline
\end{tabular}


Journal of Enterprising Culture, 28(1): 1-29

Table 5 - Multiple linear regression

\begin{tabular}{|c|c|c|}
\hline & M1 & $\mathrm{M} 2$ \\
\hline GENDER & -.004 & -.024 \\
\hline NATIONALITY & .044 & .108 \\
\hline SENIOR & -.025 & -.045 \\
\hline \multicolumn{3}{|l|}{$\mathrm{AGE}$} \\
\hline AGE1 & -.007 & .097 \\
\hline AGE2 & -.009 & .073 \\
\hline AGE3 & -.031 & .021 \\
\hline AGE4 & -.038 & .037 \\
\hline \multicolumn{3}{|l|}{ EDUC } \\
\hline EDUC1 & .124 & .100 \\
\hline EDU2 & .159 & .183 \\
\hline \multicolumn{3}{|l|}{ EDUC3 } \\
\hline SIZE & -.078 & -.073 \\
\hline \multicolumn{3}{|c|}{ INDUSTRIAL SECTOR } \\
\hline FCP & $.309 * * *$ & $.159 * * *$ \\
\hline WEAV & .085 & .090 \\
\hline EMBR & -.099 & .025 \\
\hline SPFINISH & -.071 & -.005 \\
\hline INNOV1 & & $.228 * * *$ \\
\hline INNOV2 & & $.296 * * *$ \\
\hline PROACT1 & & $.262 * * *$ \\
\hline PROACT2 & & .054 \\
\hline RISK & & $.105^{*}$ \\
\hline$\overline{\mathrm{R}^{2}}$ & .152 & .627 \\
\hline Adj. $R^{2}$ & .092 & .590 \\
\hline $\mathrm{F}$ & $2.518^{*}$ & $17.216^{* * *}$ \\
\hline F-change & $2.518^{*}$ & $52.119 * * *$ \\
\hline
\end{tabular}

